\title{
DE \\ DOI: 10.1515/orga-2015-0020 \\ Impact of Population Ageing on Unemployment and Entrepreneurial Activity: the Case of Slovenia
}

\author{
Marjetka Troha Akanni ${ }^{1}$, Žiga Čepar ${ }^{2}$ \\ ${ }^{1}$ Lekšan d.o.o. Bloška Polica 8, SI-1384 Grahovo, Slovenia \\ marjetka.troha@gmail.com \\ 2University of Primorska, Faculty of Management, Cankarjeva 5, SI-6000 Koper, Slovenia \\ ziga.cepar@fm-kp.si
}

\begin{abstract}
Purpose: The purpose of the research is to investigate impact of population ageing on unemployment and entrepreneurial activity in Slovenia since it is one of the topical issues in an ageing Europe and has many implications for economic and non-economic welfare.

Design and Methodology: First, we introduce the phenomenon of population ageing and provide some literature review on population ageing impact on unemployment and entrepreneurial activity. Second, we employ multiple regression analysis on cross-section data for Slovenian municipalities. We use secondary data collected from databases of Statistical Office of Republic of Slovenia and Employment Service of Slovenia on demographic and economic variables by 210 municipalities for the year 2009.

Results: The regression analysis results confirm our first hypothesis: municipalities with higher ageing index and higher average age also have higher registered unemployment rate. If ageing index (average age) is higher by $1 \%$, the registered unemployment rate is higher on average by $0.532 \%$ to $0.670 \%$ (by $2.431 \%$ to $3.379 \%$ ), ceteris paribus. Our regression analysis also confirms our second hypothesis: municipalities with higher average age also have lower number of enterprises per 100 population. If average age is higher by $1 \%$ (by 1 year), the number of enterprises per 100 population is lower on average by $1.7 \%$ (by 0.182 enterprises), ceteris paribus.

Conclusion: We may conclude that population ageing without properly addressing it, consequently leads into lower economic welfare. That additionally highlights the importance of a proper demographic and social policy when governing labour market policy.
\end{abstract}

Keywords: unemployment; entrepreneurship; population ageing; labour market; Slovenian municipalities

\section{Introduction}

The fundamental motivation for our research is the significant and mostly unfavourable process of population ageing in Slovenia, across Europe and also in many other countries because of the various economic consequences that arise from those demographic changes. Moreover, the evident population ageing has not only economic consequences, but also social, psychological, cultural, institu- tional and political consequences (Malačič, 2008, 795) and therefore requires changes and adjustments in many different fields of some country's system.

We found investigation of population ageing consequences especially important since population ageing affects living standard of some country, the quality of life or welfare, which however are quite a complex concepts (Mandič and Filipovič-Hrast, 2011, 16-17; Dubska, 2010, 5; Osberg and Sharpe, 2011, 1-5; Watson et al., 2010, 1-3). 
To briefly illustrate the extent of population ageing in Slovenia, we can have a look at the average age of Slovenian population which rose from 35.9 years in the year 1991 to 42.4 years in the year 2014 and ageing index from 53.6 to 120.5 in the same time period. Similarly, the share of old people (people who are 65 years old or more) in total Slovenian population increased from $12.6 \%$ to $17.7 \%$ from the year 1991 to 2014 (SORS, 2015). The long run projections forecasts natural increase in Slovenian population to be -0.9 in the year 2050 (U.S. Census Bureau, 2011), which will further increase the share of old and decrease the share of young people in Slovenian population. According to UN projections, in the year 2050, the share of old people in total Slovenian population will reach $33.1 \%$, while median age will rise up to 52.2 years (United Nations, 2006).

In Slovenia as well as in most of the other European countries, unemployment had been declining until 2008, when it reached its minimum just before the outbreak of the economic crisis. In Slovenia the unemployment rate was $4.4 \%$ and in European Union (28 countries) it was $7.0 \%$. It kept increasing until 2013, when it reached its maximum at $10.1 \%$ in Slovenia and $10.9 \%$ in European Union (28 countries). In 2013, unemployment rate was the highest in Greece (27.5\%), Spain $(26.1 \%)$, Croatia (17.3\%), Portugal (16.4\%) and Cyprus (15.9\%) and the lowest in Luxembourg (5.9\%), Austria (5.4\%), Iceland (5.4\%), Germany $(5.2 \%)$ and Norway (3.5\%) (Eurostat, 2015). According to Kurek and Rachwał (2011) employment rates in the population aged 50-64 in 2007 were highest in the Scandinavian states (Sweden, Finland) as well as in the United Kingdom and Norway (over 75\%).

Relatively high levels of employment rates were also recorded in Portugal and Denmark, with a decrease in employment in recent years. The lowest rates of employment were observed in Poland, Hungary, Italy, Belgium, Luxembourg and Slovenia (less than 53\%). On another hand in 2007 the number of small and medium enterprises per 1,000 inhabitants was 42.1 for the European Union (27 countries) and reached its highest values (over 60) in the countries of south Europe (Portugal, Spain, Italy, Greece) as well as in Sweden and the Czech Republic, while the value for Slovenia was around 45 (Kurek and Rachwał, 2011).

There are quite some studies on impact of population ageing on labour market, and also specifically on unemployment and entrepreneurship - in some cases proving a negative and in the other cases a positive impact of population ageing on unemployment and/or on entrepreneurship. We present some of those studies in the next section. Of course a variety of factors, including those related to the global economic slowdown, may affect the unemployment rate and entrepreneurial activity, so population ageing is definitely not the primary or the only factor. Some of these other factors are briefly discussed in the next section.
However our focus in this study is particularly on population ageing.

The main motivation and reason for our own research in this field is therefore to provide new empirical evidence which would support the first or the second group of researchers and to provide some original specific findings about the relationship between population ageing and unemployment as well as population ageing and entrepreneurship based on cross section data in the case of Slovenian municipalities, which has not been done yet in any other study. The results of our research and answers to our research questions contribute to the existing body of research about impact of population ageing on labour market; yet again it is worth exploring that subject since population ageing implications directly and indirectly impact the quality and standard of our lives.

We would like to answer two research questions. First: what can be found out about the impact of population ageing on unemployment in case of Slovenia? And second: what can be found out about the impact of population ageing on entrepreneurial activity in case of Slovenia? Unemployment and entrepreneurial activity are important labour market aspects, are highly interrelated and this is also why we wanted to analyse them together in one study. Higher level of entrepreneurial activity also means higher number of enterprises, higher number of new workplaces which finally impact unemployment and the demand and supply side of the labour market. Entrepreneurship is a very complex concept with many different aspect and dimensions (Wach, 2015), however in this study, entrepreneurial activity is interpreted in a narrow sense and is proxied with the relative number of enterprises.

In the next section we review some previous research about effects of population ageing on unemployment and entrepreneurial activity which is also the focus of our own investigation.

\section{Theory and Literature Review on Impact of Population Ageing on Un- employment and Entrepreneurship}

In order to provide some theoretical discussion and background on which we build our hypotheses we here first review some basic unemployment theories and later on findings of the studies on impact of population ageing on unemployment and entrepreneurship.

\subsection{Unemployment Theories}

Unemployment occurs when people are without work and are actively seeking work. It is measured by the unemployment rate, which is calculated as a percentage by dividing the number of unemployed individuals by all individuals currently in the labour force (employed and unemployed). 
Theories of unemployment explain causes, consequences and offer solutions for unemployment. Classical economics, New classical economics, and the Austrian School of economics argue that market mechanisms are reliable means of resolving unemployment - no government intervention is needed. Keynesian economics emphasizes the cyclical nature of unemployment and recommends government interventions in the economy that is supposed to reduce unemployment during recessions (Layard et al. 2005).

According to the different reasons why unemployment occurs, labour market theory most commonly lists structural, frictional, cyclical and classical unemployment. Classical or real-wage unemployment occurs when real wages for a job are set above the equilibrium level, causing the quantity of labour supplied to exceed the quantity of labour demanded.

Cyclical or Keynesian unemployment occurs when there is not enough aggregate demand in the economy to provide jobs for everyone who wants to work. Due to the decrease in aggregate demand, less production and consequently fewer workers are needed. Because wages are sticky and do not fall to meet the equilibrium level cyclical unemployment occurs. Structural unemployment focuses on structural problems in the economy and inefficiencies such as a mismatch between the supply and demand of workers with necessary skill sets. Frictional unemployment depends on the time period between jobs when a worker is searching for or transitioning from one job to another. It focuses on voluntary decisions to work based on each individual's valuation of their own work and how that compares to current wage rates plus the time and effort required finding a job. Voluntary unemployment - most of the frictional unemployment - is attributed to the individual's decisions, whereas involuntary unemployment - most of the cyclical, structural and classical unemployment - exists because of the socio-economic environment (Layard et al. 2005). Population ageing can trigger some changes in causes for unemployment which is further discussed in the next section.

\subsection{Impact of Population Ageing on Un- employment}

Literature review reveals that there is no general consensus on whether population ageing increases or decreases general rate of unemployment. There are many channels through which population ageing impacts unemployment rates of young and old and consequently the general rate of unemployment which is a result of changes in some population's age structure on one hand and changes of age specific unemployment rates on the other hand.

There are several channels through which population ageing might decrease population general rate of unemployment. Bratić and Vukšić (2014) in their study on Cro- atian population found out that compared to older workers younger workers predominantly have fixed-term employment contracts, what means that they can be much more easily fired than older workers. If older workers have more permanent contracts compared to younger workers who predominantly get a fixed term contract at least for the first job, consequently older people are less likely to lose a job and to become unemployed, while most of young people even need to find their first job. As a result there is higher unemployment among young compared to old people and thus older society with higher share of old and lower share of young people will exhibit lower general rate of unemployment (Eichhorst, 2013). Additionally, younger people have higher unemployment rates due to higher job separation rates (Gervais et al., 2014).

Studies conducted by Bell (2011), Cahuc et al. (2013) and Dunsch et al. (2015) show that fluctuations in economic activity and recessions affect unemployment of young more than unemployment of old. This again means that older societies with higher share of old workers are less vulnerable to economic shocks and keep higher employment rates compared to younger societies.

Population ageing brings not only huge economic, but also social and political changes (Stanovnik and Stropnik, 1999, 1-5). As population is ageing, there are more and more old people involved in politics or are being members of national parliaments. Consequently, specific laws and social measures confirmed by the parliaments are more in favour of older than younger people, which is reflected also in a relatively lower unemployment of old people. Since their share is relatively increasing in total workforce, the general unemployment is decreasing (Hughes, 2011). Older unemployed people are compared to the young ones more likely to switch from unemployment or sickness benefits to disability or to early retirement which takes them out of the labour force and thus reduces unemployment (McDougall, 2010; Lammers et al., 2013).

Young people do not have these possibilities or are these possibilities much less likely to take place. Bratberg et al. (2004) in a study of a Norwegian early retirement program found out that at least $50 \%$ of the early retirement program retirees would have stayed in the labour force without that program. However, removing older workers from labour force into retirement does not reduce youth unemployment (Jousten et al., 2010; Samorodov, 1999).

Eriksson and Dan-Olof (2014) argue that young people have higher unemployment rate also since they are less likely to get a job because they have fewer work experiences compared to older people. Eriksson and Dan-Olof (2014) talk about stigma of "being without a job", which is primarily young job seekers stigma. Besides there are many other obstacles that young people face in the transition from education to work which additionally increase youth unemployment rates compared to older people (Weber and Lehtinen, 2014). 
Finally, population ageing will in its final stage result in shrinking labour force when most of the baby-boomers will exceed their retirement age and exit labour force (Penger and Dimovski, 2007, 42). Eventually, there will come to a labour force shortage and shortage in critical organisational knowledge and managerial experience (CEDEFOP, 2012), which will result in reduced unemployment and increased labour cost (Jackson, 2011). Lisenkova et al. (2010) already noticed that the fall in population, and particularly working-age population in Scotland, has a depressing impact on economic activity. The required size of the annual net-migration needed to neutralize the adverse natural demographic changes is even higher than the current trends.

On the other hand, there are also channels through which population ageing increases population general rate of unemployment. In general, population ageing is increasing unemployment rate because older workers are less likely to find a job when losing one, compared to the younger workers. Older workers are less educated, less flexible; find it more difficult to move, to drive longer to the place of work, and to switch among different areas of work. They are less mobile in terms of geographic and sectorial mobility compared to younger workers (Dixon, 2003).

Chéron et al. (2013) confirms that job search by the unemployed falls with age. Older people are less motivated to look for a new job when being unemployed, since the time period in which employees benefit from a job is getting shorter with age. Consequently older people exhibit higher unemployment rates compared to younger ones, holding other things constant.

Older people are generally on average less educated (Čepar and Bojnec, 2008), so are older workers compared to the younger ones (Dolado, 2000; Dimovski and Žnidaršič, 2007, 2-15), and less educated workers have higher unemployment rates (Málaga et al., 2014; Zhang et al., 2015; Rapa, 2014; Gelagay, 2015) which again increases the unemployment rate of older populations.

On one hand, because older people tend to have higher salaries and many age related salary supplements due to the higher number of years of employment, they represent a higher labour cost to the employers. On the other hand they are also less productive which is also due to a higher risk for health issues (Börsch-Supan and Weiss, 2007; Conen et al. 2012; Auer and Fortuny, 2000). So employers will prefer to hire younger workers who are generally cheaper and more productive (Skirbekk, 2003). Consequently unemployment of older workers is higher and when the share of old people is increasing in total workforce, the general rate of unemployment must increase too. Higher unemployment among older people compared to the general unemployment rate in European Union is found also by Laporšek and Dolenc (2011).

Michaelis and Debus (2010) argue that an increase in the relative number of older workers might have no effect on unemployment rate of old workers. However, if unions negotiate higher wages for the old, the unemployment rate of the old will increase.

Another important channel through which population ageing influences unemployment is the change in demand structure. Each age group has its specificities in demand; we say that demand is also age specific. Young people tend to demand for some goods that are less interesting for old people and vice versa. We may expect an increasing demand for services in health care sector (Lešnik-Hren, 2003, 887 ), in education of adults and life-long learning and in leisure related sectors like tourism. Consequently demand in these sectors will expand and so will the demand for labour in these sectors. So, changes in age structure result in changes in the demand structure (Aigner-Walder and Döring, 2015). Furthermore, as the demand structure of the economy changes, a shift in labour force between industries should occur to meet the demand shift, but due to various labour market frictions, structural and frictional unemployment rates are likely to increase during that shift (Borsch-Supan, 2003; Fougere et al., 2007; Rausch, 2009). In Japan study, Katagiri (2012) also presents some evidence of the inability of labour force to adapt immediately to the changes in labour demand.

\subsection{Impact of Population Ageing on En- trepreneurship}

Some studies show that population ageing might negatively affect entrepreneurial activity, since age is supposed to negatively affect entrepreneurial activity. Liang (2014) argues that creativity may decline with age, but business skills increase with experience in high level positions. However, having too many older workers in society slows entrepreneurship. Not only are older workers less innovative less educated and less creative.

When older workers occupy key positions they block younger workers from acquiring business skills. In his study, Liang (2014) found out that a one-standard deviation decrease in the population median age increases the new business growth by 2.5 percentage points. Besides, older societies have lower rates of entrepreneurship at every age. Many different researches also confirm the close interrelation between entrepreneurship and unemployment. New enterprises create new jobs and consequently reduce unemployment (Startiene and Remeikiene, 2009). If entrepreneurship is really less present in older societies that also means that older societies will have higher unemployment rates.

On another hand population ageing might positively affect entrepreneurial activity. That could be a consequence of the new business opportunities arising from the particular demand and needs of the growing population of people who are over 50 years old. These new market opportunities 
are also referred to as silver economy which is related not only to private consumer expenditure but also to public expenditure. In any case, the sliver economy, which provides opportunities for new jobs also in the field of healthy ageing, senior tourism and age-friendly housing, has been growing substantially (European Commission, 2015).

Since we know that population ageing might increase unemployment, we can observe impact of population ageing on entrepreneurship also indirectly through changes in unemployment. In some cases, the state supports the foundation of businesses by the unemployed (Hinz and Jungbauer-Gans, 1999), so we might find a positive impact of unemployment on entrepreneurship through government incentives for the unemployed who decide to start their own business as also through some other channels like increased motivation to find a way out of unemployment (Thurik, 2003; Thurik and Verheul, 2003; Thurik et al., 2008; Rabarijaona, 2015). Thus, population ageing might indirectly (through an increased unemployment) increase entrepreneurial activity. Yet, on another hand, Marič et al. (2013) in their regression analysis cannot confirm that unemployment rate has statistically significant influence on entrepreneurial activity.

Obviously there is a vast body of empirical research which has been published so far presenting various examples of population ageing impact on unemployment and entrepreneurial activity. Some investigations prove that population ageing is increasing unemployment and worsening labour market conditions; while other researches confirm that in some cases population ageing decreases unemployment. Similarly the influence of population ageing on entrepreneurship is found to be positive in some cases and negative in the other. Depends on the sum of all the effects working through different channels and specific socio-economic circumstances a particular population is faced with.

Based on evidence derived from our own quantitative study on data for Slovenia, we wanted to test whether we can present additional evidence which would support those who prove the positive or those which prove the negative impact of population ageing on unemployment and/ or entrepreneurial activity.

There are also many other different consequences of population ageing, apart from those mentioned in that literature review and that have also been explored in different contexts and different relations (Obadić and Smolić, 2008; Pešić, 2009). Population ageing affects public as well as private sector which further on affects investment, pension system, public health care system, tax rates and wage growth. Countries with older workforce and higher share of retired people have lower rate of savings which lowers the real value of money paid out from pension funds. Therefore, pension reform is urgently needed (Miles, 2005, 1-3). However, in the rest of the paper we are focusing on the empirical investigation of influence of population ageing on unemployment and entrepreneurial activity only.

\section{Methods}

In the following section we present the research hypotheses and the methodology which was used to achieve the goals of the research and to test the research hypotheses. Next we present the assumptions on which our research is based as well as its limitations in a sense of its scope, geographical limits and time frame. Finally the most important data used in this investigation is explained.

\subsection{The Research Hypotheses}

It is obvious from the studies mentioned at the beginning of the paper in Introduction and especially from the review of the relevant recent studies that there are many different consequences of population ageing for some economy, labour market and particularly for unemployment and entrepreneurial activity. In our research we wanted to statistically test the effects of population ageing on unemployment and entrepreneurial activity, using cross section data about 210 Slovenian municipalities in the chosen year 2009. Our main research thesis is: Population ageing is an important factor, which significantly unfavourably impacts labour market in Slovenia. In order to systematically test the main research thesis, we set the following two hypotheses.

Hypothesis 1: Older populations have higher unemployment rate.

Hypothesis 2: Older populations have lower entrepreneurial activity.

In our investigation, the expression "older population" is not used to describe some chosen age group of people in a static way. It is used in a comparative way in the following sense. A population of some municipality is older than the other if it has higher ageing index or higher average age. How are these two population ageing indicators calculated is shown in section "Data used". We simply wanted to empirically test if municipalities with higher ageing index or higher average age (municipalities which are older) also have higher unemployment rates and lower relative number of enterprises and how strong is this effect.

An observation unit in our case is a Slovenian municipality, a population which can be older or younger than the other and also different in the unemployment and entrepreneurial activity than the other. We can see from the review of the recent studies about the impact of population ageing on unemployment and entrepreneurship, in section which addresses literature review, that that impact could be very different. We believe that there is an unfavourable impact of population ageing on unemployment and entrepreneurship; and this is why we set these two hypotheses. 
Using the regression analysis presented in the next section, we will be able to reject or to confirm our two hypotheses.

\subsection{Quantitative Methodology Used}

In order to test the main research thesis and the two hypotheses set, we run several regression models. First, we collected secondary data from the databases of Statistical office of Republic of Slovenia (SORS, 2011a; SORS, $2011 \mathrm{~b}$ and SORS, 2011c) and Employment Service of Slovenia (ESS, 2011). The data refer to several demographic and economic variables by 210 Slovenian municipalities for the year 2009. So, observation units are Slovenian municipalities. The cross section data enable us to exclude any time related effects from the analysis, like economic slowdown and other changes which occur through time. More details about the data used are given in section "Data Used" below. The cross section demographic and economic data were properly arranged, transformed and entered into a statistical computer package SPSS, which was used for regression analysis.

First, bivariate and later also multivariate linear and log-linear regression models were conducted in order to analyse the connection between variables which measure population age structure and variables which measure labour market conditions in Slovenia.

Variables, which measures labour market conditions in Slovenia were used as dependent variables and variables, which measure population age structure were used as explanatory variables. We set assumptions about the relationships and association among several different variables used and set regression models which were tested on the available data about the Slovenian municipalities.

Using regression analysis we estimated parameters of the models and chose the best fitting models based on the standard error of the models, adjusted determination coefficient, F-tests and t-tests. In the regression analysis, some control variables were employed too, in order to eliminate their effects from the explanatory power of the demographic variables.

In order to test the first hypothesis the following general regression model was tested:

- registered unemployment rate $=f($ constant; population ageing indicators; control variables; error term н)

In order to test the second hypothesis the following general regression model was tested:

- number of enterprises per 100 population $=f($ constant; population ageing indicators; control variables; error term $\mu$ )

\subsection{Research Assumptions and Limita- tions}

Assumptions of our investigation are mostly related to the indicators which are used to measure population ageing and labour market conditions. We also assume that relative number of enterprises is positively and rate of registered unemployment is negatively associated with labour market conditions.

Limitations of our investigation narrow the scope of investigation and address some methodological problems. Most important limitations are the following. The research is conducted using data for all Slovenian municipalities; consequently, the results of the research are valid for the whole Slovenia. However, generalisation of those results on other countries is limited due to the specificities of those other countries. When analysing unemployment we used data on registered unemployment only, which are available by particular years and municipalities.

The survey unemployment data (ILO) were not used, since they are available for the whole aggregate level of Slovenia only. When we used control variables, the size of a municipality was measured by the number of its population and the gross investment by the number of enterprises. Due to the data confidentiality, the data on gross investment by municipalities were not available. Entrepreneurial activity is interpreted in a narrow sense only and is quantified with the relative number of enterprises. There are many other factors of unemployment and entrepreneurial activity apart from those analyzed in our study. However in this study we focus on population ageing only as a factor of unemployment and entrepreneurial activity.

\subsection{Data Used}

All secondary data were collected from the databases of Statistical office of Republic of Slovenia (SORS, 2011a; SORS, 2011b and SORS, 2011c) and Employment Service of Slovenia (ESS, 2011). The data refer to several demographic and economic variables by 210 Slovenian municipalities for the year 2009. The exact web links to the statistical databases are in the reference list at the end of the paper next to the corresponding reference. 


\section{Demographic data}

Demographic data were mostly used to measure population ageing. Below is a list of demographic data used in regression analysis.

- Average population age is defined as a weighted arithmetic mean of a certain group of people (SORS, 2002). It is calculated as:

$$
X=\frac{\sum(x+0,5) * P_{x}}{\sum P_{x}}
$$

where:

$\mathrm{X}$ - average population age

$\mathrm{X}$ - age or one-year age group

$\mathrm{P}_{\mathrm{x}}$ - number of people who are $\mathrm{x}$ years old

- Ageing index is calculated as the number of persons 65 years old or over per hundred persons under age 15 (SORS, 2002):

$$
A_{I}=\frac{P_{(65+)}}{P_{(0-14)}} * 100
$$

where:

$\mathrm{A}_{\mathrm{I}}$ - ageing index

$\mathrm{P}_{(65+)}-$ population 65 years old or over

$\mathrm{P}_{(0-14)}=$ population under age 15

- Natural population increase per 1,000 population is the rate between the difference between the number of live births and the number of deaths of a chosen area in a chosen calendar year in a numerator and the number of population in the middle of the same year and of the same area in the denominator multiplied by 1,000 (SORS, 2002):

$$
n i=\frac{N I}{P_{(30.6 .)}} * 1000
$$

where:

ni - natural population increase per 1,000 population $\mathrm{NI}$ - absolute natural increase (difference between number of live births and deaths)

$\mathrm{P}_{(30.6)}$ - the number of population on June the $30^{\text {th }}$ of a chosen year

\section{Data on labour market}

The data below were used in a regression analysis to measure labour market conditions.

- Registered unemployment rate is defined as the ratio between the number of registered unemployed people and economically active population multiplied by 100 (SORS, 2014):

$$
U_{\%}=\frac{\sum P_{(\text {reg.unempl. })}}{\sum P_{(\text {working })}+P_{(\text {reg. anempl. })}} * 100
$$

where:

$\mathrm{U}_{\%}$ - registered unemployment rate

$\mathrm{P}_{\text {(reg. unempl.) }}$ - number of registered unemployed population

$\mathrm{P}_{\text {(working) }}-$ number of working population

- The number of enterprises per 100 population in a municipality. In bigger municipalities one would expect more enterprises than in smaller municipalities. We measured the size of a municipality by the number of population in a municipality. In order to eliminate the effect of different sizes of municipalities on the number of enterprises, we calculated a relative measure so that we divided the absolute number of enterprises in a chosen municipality by the number of total population that municipality and multiplied the ration by 100 .

$$
\text { ENT per } 100 \text { pop. }=\frac{E N T_{x}}{P_{(x, 31.12 .)}} * 100
$$

where:

ENT per 100 pop. - the number of enterprises per 100 population in a municipality $\mathrm{x}$

$\mathrm{ENT}_{\mathrm{x}}$ - the number of all enterprises in a municipality $\mathrm{x}$ $\mathrm{P}_{(\mathrm{x}, 31.12 .)}$ - the number of total population in a municipality $\mathrm{X}$

\section{Control variables}

In our regression analysis, we included additional independent variables in order to control for the "size of the municipality" (measured by the number of population), "the existence of a university in a municipality" and "the number of enterprises in a municipality". By the size of the municipality we tried to capture the positive synergies and economies of scale that may occur in bigger municipalities. By the existence of an university in a municipality we wanted to capture the positive effects of the availability and accessibility of higher education and the many other positive effects of an university on the local environment. By the number of enterprises we wanted to capture the economic activity by municipalities. When analysing the dependence of economic welfare on the population ageing, we wanted to test, whether the presence of the control variables changes the results of the regression analysis or not.

\section{Econometric Results}

In order to test each of the two hypotheses we run several bivariate and multivariate linear and logarithmic regressions. The latter ones were actually linear regressions (linearized logarithmic regressions) too, only with logarithmically transformed data. In all the regression models we analysed the explanatory power of the independent explanatory demographic variables as well as the strength and the direction of the association between the dependent variable (indicator of unemployment) and dependent vari- 
able (indicator of population ageing). Using regression and correlation coefficients we tested the existence and the direction (positive/negative) of the association and impact that was assumed for each factor in each hypothesis. Using adjusted determination coefficient we wanted to test the share of the variance that could be explained by the independent variables. On the basis of t-test results we tested statistical significance of each individual explanatory variable, where on the basis of F-test results we tested statistical significance of the regression model as a whole. During regression analysis we run many different models, however only those which were significant and those with highest explanatory power were selected for interpretation in this paper. A similar procedure was repeated, when also control variables were entered into the above regression models. After control variables were entered into the initial regression models, we checked if the direction of the influence or statistical significance or the explanatory power of the explanatory demographic variable were changed or not and again for final interpretation used the most appropriate models. The various theoretical views and interpretations of the other researchers were thus upgraded with our own original empirical findings regarding the interrelation between population ageing and economic welfare.

\subsection{Results of the regression analysis of the first hypothesis}

Hypothesis 1: Older populations have higher unemployment rate.

We run several linear and non-linear regression models where the rate of registered unemployment (measuring one aspect of labour market) was a dependant variable and ageing index, populations average age (both measuring population ageing) together with some control variables were independent variables.

Our intention was not to find all the factors that influence registered unemployment, but to show that population ageing is one of them and this is why we started with bivariate models. Here we finally present some of the best models according to the statistical significance of the variables, adjusted determination coefficient value and statistical significance of the model as a whole. It soon turned out that, log-linear models show better results than models related to other mathematical functions. Model 1 is the regression model which includes explanatory variables with statistically significant coefficients presented in the first row of table 1; model 2 is the regression model which includes explanatory variables with statistically significant coefficients presented in the second row of table 1; model 3 is the regression model which includes explanatory vari-

Table 1: Regression models results - logarithm of the registered unemployment rate depending on the logarithm of the population ageing indicators and control variables

\begin{tabular}{|c|c|c|c|c|}
\hline & \multicolumn{4}{|c|}{$\begin{array}{l}\text { Regression coefficient }(\beta) \\
\text { (and exact significance levels in the brackets) }\end{array}$} \\
\hline & Model 1 & Model 2 & Model 3 & Model 4 \\
\hline Constant & $-0.137(0.051)$ & $-4.498(0.000)$ & $-4.019(0,025)$ & $-0.725(0.032)$ \\
\hline Log. of ageing index & $0.532(0.000)$ & 1 & 1 & $0.670(0.000)$ \\
\hline Log. of average age & 1 & $3.379(0.000)$ & $2.431(0.016)$ & 1 \\
\hline Log. of number of population & 1 & 1 & $0.454(0.000)$ & $0.650(0.000)$ \\
\hline Log. of number of enterprises & 1 & 1 & $-0.473(0.000)$ & $-0.618(0.000)$ \\
\hline F-test & $22.698(0.000)$ & $30.732(0.000)$ & $\begin{array}{l}15.799 \\
(0.000)\end{array}$ & $18.515(0.000)$ \\
\hline $\begin{array}{l}\text { Adjusted determination } \\
\text { coefficient }\left(\mathbf{R}^{2}\right)\end{array}$ & 0.094 & 0.125 & 0.175 & 0.201 \\
\hline
\end{tabular}

Dependent variable: Logarithm of registered unemployment rate

Number of units observed (N): 210

Source: own calculations based on the data collected from SORS, 2011a; SORS, 2011b; SORS, 2011c 
ables with statistically significant coefficients presented in the third row of table 1 and model 4 is the regression model which includes explanatory variables with statistically significant coefficients presented in the fourth row of table 1; while the dependant variable is always logarithm of registered unemployment rate.

As we can see from regression analysis results in table 1, all the included independent variables in all four regression models are statistically significant (t-tests), while F-test shows that all four models as a whole are statistically significant too. Based on t-tests (sig. $(\mathrm{t})<0.05)$ and based on F-tests (sig. $(\mathrm{F})<0.05$ ), we may always reject the null hypothesis that there is no influence of the logarithm of the population ageing indicator on the logarithm of the registered unemployment rate, taking almost no risk of making the type I error (which would be the incorrect rejection of a true null hypothesis). Thus we may conclude from all the four models that the population ageing has an influence on the registered unemployment rate in Slovenia.

Adjusted determination coefficient (adj. $\left.\mathrm{R}^{2}\right)$ tells us how much of the variation of the logarithm of the registered unemployment rate could be explained by the variation of the logarithms of the in the model included population ageing indicators and control variables by the Slovenian municipalities $(9.4 \%$ in the first model, $12.5 \%$ in the second model, $17.5 \%$ in the third model and $20.1 \%$ in the fourth model).

We expected the determination coefficients not to be too high, since there are obviously many other factors of registered unemployment rate, which were not included into the regression analysis. However our main purpose was simply to show that population ageing itself has some significant impact on registered unemployment rate even when control variables (the size of a municipality measured by the number of population and the number of enterprises) are included like in the model 3 and model 4. According to the regression analysis results, higher number of enterprises decrease registered unemployment rate, while higher number of people (probably because such population is older) increases the registered unemployment rate.

When ageing index is increased by $1 \%$, the registered unemployment rate is increased on average by $0.532 \%$ (model 1 ) or by $0.670 \%$ holding other variables constant when control variables are included (model 4). The ageing index recorded in 2009 in Slovenia was 116, meaning that there were on average 116 persons who are 65 years old or over per hundred persons under age 15 .

When average age is increased by $1 \%$, the registered unemployment rate is increased on average by $3.379 \%$ (model 2 ) or by $2.431 \%$ holding other variables constant when control variables are included (model 3). The average age of Slovenian population recorded in 2009 in Slovenia was 41.2 years.

\subsection{Results of the regression analysis of the second hypothesis}

Hypothesis 2: Older populations have lower entrepreneurial activity.

Also in order to test our second hypothesis we run several regression models; however we present here only those which were most statistically significant and consistent. Model 1 is the final regression model which includes explanatory variables with statistically significant coefficients presented in the first row of table 2 ; model 2 is the final regression model which includes explanatory variables with statistically significant coefficients presented in the second row of table 2; and model 3 is the final regression model which includes explanatory variables with statistically significant coefficients presented in the third row of table 2. The dependant variable is always (logarithm) of the number of enterprises per 100 population. The methodological reasoning for the choice of the three presented models was the same as in case of the first hypothesis.

Adjusted determination coefficient (adj. $R^{2}$ ) tells us how much of the variation of (the logarithm of) the number of enterprises per 100 population could be explained by the variation of (the logarithms of) the in the model included population ageing indicators and control variables by the Slovenian municipalities $(1.9 \%$ of the variation in model 1, 11.9\% in model 2 and $16.1 \%$ in model 3). Again, we expected the determination coefficients not to be too high, since there are obviously many other factors of the number of enterprises per 100 population, which were not included into the regression analysis.

However our main purpose was simply to show that population ageing itself has some significant impact on the number of enterprises per 100 population even when control variable - the size of a municipality measured by the number of population - is included (model 2). According to the regression analysis results, bigger size of a municipality (measured by the number of people) increases the registered unemployment rate (table 2).

The beta regression coefficients from table 2 show the following. When average age is increased by $1 \%$, the number of enterprises per 100 population is decreased on average by $1.7 \%$ (model 1 ). The average number of enterprises per 100 population recorded in 2009 in Slovenia was 6.4. When average age is increased by 1 year the number of enterprises per 100 population is decreased on average by 0.182 , holding other variables constant (model 2).

When the number of population is increase by 1 person the number of enterprises per 100 population is increased on average by 3.239 , holding other variables constant (model 2). When the natural population increase per 1,000 population is increased by $1 \%$ the number of enterprises per 100 population is increased on average by $0.86 \%$ 
(model 3). The average natural population increase per 1,000 population recorded in 2009 in Slovenia was 1.479 persons.

\section{Discussion}

Based on the results of our empirical investigation we may answer our first research question by concluding that municipalities with higher population average age and higher ageing index have higher registered unemployment rate in Slovenia. That conclusion is drawn from the regression analysis. In order to test our first hypothesis, we also run multivariate regression models with control variables. Even, when the control variables are employed in the model, the direction of an influence of demographic variables on registered unemployment rate stays the same and the statistical significance is still ensured. Moreover, according to the regression analysis results, higher number of enterprises in a municipality results in lower registered unemployment, which is consistent also with some previous studies. We may confirm our first hypothesis that older populations have higher unemployment rate. Consequently they also have lower economic welfare.

The results of our research answer also our send research question about the impact of population ageing on entrepreneurial activity. If the average age is higher, the number of enterprises per 100 population is lower. Moreover, when natural population increase is higher, the num- ber of enterprises per 100 population is higher too. We assume of course, that higher natural population increase is associated with younger populations.

When the control variables are entered into the regression models, the direction of an influence of demographic variables on the number of enterprises per 100 population stays the same and the statistical significance is still ensured. The control variable the size of a municipality (measured by the number of population in a municipality) has a positive influence on entrepreneurial activity, since bigger municipalities have positive effects of economies of scale, have better developed infrastructure and have other positive externalities which encourage entrepreneurship. Obviously we may confirm our second hypothesis that older populations have lower entrepreneurial activity. Consequently they also have lower economic welfare. Lower entrepreneurial activity also leads into lower number of new working places in such municipalities and therefore into higher registered unemployment rate, which is also consistent with some of the previous studies mentioned in the literature review.

The results of our research might be used as an empirical argument when developing basis for governing economic policy. The findings imply, that demographic processes significantly impact labour market, meaning that proper demographic policy might also be taken into account as an instrument of a labour market policy in a wider sense.

Table 2: Regression models results - (logarithm of) the number of enterprises per 100 population depending on (logarithm of) the population ageing indicators and control variables

\begin{tabular}{|c|c|c|c|}
\hline & \multicolumn{3}{|c|}{$\begin{array}{l}\text { Regression coefficient }(\beta) \\
\text { (and exact significance levels in the brackets) }\end{array}$} \\
\hline & Model 1 & Model 2* & Model 3 \\
\hline Constant & $3.965(0.005)$ & $18.683(0.000)$ & $0.701(0.000)$ \\
\hline Logarithm of average age & $-1.728(0.025)$ & I & I \\
\hline Average age & l & $-0.182(0.014)$ & l \\
\hline $\begin{array}{l}\text { The size of a municipality } \\
\text { (the number of population) }\end{array}$ & l & $3.239(0.000)$ & l \\
\hline $\begin{array}{l}\text { Logarithm of the natural } \\
\text { population increase }\end{array}$ & l & / & $0.086(0.000)$ \\
\hline F-test & $5.130(0.025)$ & $15,180(0.000)$ & $24.397(0.000)$ \\
\hline $\begin{array}{c}\text { Adjusted determination } \\
\text { coefficient }\left(\mathbf{R}^{2}\right)\end{array}$ & 0.019 & 0.119 & 0.161 \\
\hline
\end{tabular}

Dependent variable: Logarithm of the number of enterprises per 100 population ("In model 2 dependent variable is: The number of enterprises per 100 population)

Number of units observed (N): 210

Source: own calculations based on the data collected from SORS, 2011a; SORS, 2011b; SORS, 2011c 


\section{Conclusion}

From the literature review we can see that some studies reveal a negative and some a positive impact of population ageing on unemployment and entrepreneurial activity. Yet our research confirms our main thesis that population ageing is an important factor, which significantly unfavourably impacts labour market conditions in Slovenia and consequently economic welfare. First, through increasing unemployment and second, through decreasing entrepreneurial activity.

Most probably that could be explained by the lower flexibility of the ageing labour force, its higher labour cost, outdated knowledge and competencies, lower level of innovativity, creativity and higher aversion to risk taking. Thus we bring forward another empirical evidence of the unfavourable impact of population ageing on unemployment and entrepreneurial activity which is also consistent with some other previous research (Chéron et al., 2013; Málaga et al., 2014; Zhang et al., 2015; Rapa, 2014; Gelagay, 2015; Dixon, 2003; Conen et al. 2012; Fougere et al., 2007; Rausch, 2009; Katagiri 2012; Liang, 2014; Startiene and Remeikiene, 2009).

However on the other hand we may also find studies in the literature which imply the oppostite-that population ageing decreases unemployment and increases entrepreneurial activity (Bratić and Vukšić 2014; Eichhorst, 2013; Gervais et al., 2014; Bell, 2011; Cahuc et al., 2013; Dunsch et al., 2015; Hughes, 2011; McDougall, 2010; Lammers et al., 2013; Jousten et al., 2010; Eriksson and Dan-Olof, 2014; Jackson, 2011; Thurik et al., 2008; Rabarijaona, 2015). We must keep in mind that general rate of unemployment is actually a weighted average of the unemployment rate of old and unemployment rate of young, so it depends not only on both partial unemployment rates, but also on the population's age structure.

And that population age structure is changing in when population ageing takes place. Both, unemployment and entrepreneurial activity obviously have many partial factors in behind which work in different directions. So how will unemployment or entrepreneurial activity finally change, when population is ageing, depends on the final "sum" of the different directions of impacts of all different factors.

Moreover, our findings are not only about the direction of the impact (positive/negative) but also offer detailed quantitative measures of the strength and significance of the partial influences of the population ageing on unemployment and entrepreneurship.

We see the findings of our study as another proof, that younger populations are still more competitive in terms of human capital, compared to the old ones, meaning that population ageing, holding other things constant, is a negative process, which negatively affects a society's economic welfare and wellbeing. In this context higher fertility and higher number of children per family would mean higher and not lower prosperity and welfare in a long run as it is speculated sometimes.

The main scientific contribution of this research are the original findings regarding the strength and the direction of the influence of population ageing indicators on unemployment and entrepreneurial activity based on all 210 Slovenian municipalities in a chosen year.

Challenges for our further investigation are broadening the scope of the research also with inclusion of other indicators of economic and non-economic welfare like culture, recreation, psychological health, the level of social care, free time; and with an analysis of the dynamics of the influence of population ageing on economy over longer period of time based on time series data. Another interesting question is why such phenomenon as population ageing occurs, which could be further investigated also within a qualitative research searching for the background causes for the critical development of population ageing factors.

\section{References}

Aigner-Walder, B., \& Döring, T. (2015). The effects of population ageing on private consumption - a simulation for Austria based on household data up to 2050 . Eurasian Economic Review, 2(1), 63-80.

Auer, P., \& Fortuny, M. (2000). Ageing of the Labour Force in OECD Countries: Economic and Social Consequences. Geneva: International Labour Office.

Bell, D.N.F., \& Blanchflower, D. G. (2011). Young people and the Great Recession. Institute for the Study of Labor (IZA) Discussion Paper, No. 5674. Retrieved October 5, 2015 from http://ftp.iza.org/dp5674.pdf

Borsch-Supan, A. (2003). Labor market effects of population aging. Review of Labour Economics and Industrial Relations, 17(1), 5-44, http://dx.doi.org/10.1111/14679914.17.specialissue. 2

Börsch-Supan A., \& Weiss, M. (2007). Productivity and age: Evidence from work teams at the assembly line. MEA Discussion Paper 148-2007, MEA - Munich Center for the Economics of Aging.

Bratberg, E., Holmås, T.H., \& Thøgersen, Ø. (2004). Assessing the effects of an early retirement program. Journal of Population Economics, 17(3), 387-408, http://dx.doi.org/10.1007/s00148-003-0165-y

Bratić, V., \& Vukšić, G. (2014). Fixed-term employment during transition: the Croatian experience. Eastern European Economics, 52(6), 57-76, http://dx.doi.org/10. $\underline{1080 / 00128775.2014 .1003507}$

Cahuc, P., Carcillo, S., Rinne, U., \& Zimmermann, K. F. (2013). Youth unemployment in old Europe: the polar cases of France and Germany. Institute for the Study of Labor (IZA) Discussion Paper, No. 7490. Retrieved 14.10.2015 from http://ftp.iza.org/dp7490.pdf

Chéron, A., Hairault, J.-O., \& Langot, F. (2013). 
Life-Cycle Equilibrium Unemployment. Journal of Labor Economics, 31(4), 843-882, http://dx.doi. org/10.1086/669941

Conen, W. S., van Dalen, H.P., \& Henkens, K. (2012). Ageing and employers' perceptions of labour costs and productivity: A survey among European employers. International Journal of Manpower, 33(6), 629 - 647, http://dx.doi.org/1108/01437721211261796

Čepar, Ž. \& Bojnec, Š. (2008). Population aging and the education market in Slovenia and Croatia. Eastern European Economics, 46 (3), 68-86.

Dimovski, V., \& Žnidaršič, J. (2007). Ekonomski vidiki staranja prebivalstva Slovenije: Kako ublažiti posledice s pristopom aktivnega staranja [Economic aspects of population ageing in Slovenia: How to mitigate the consequences with an active ageing approach]. Kakovostna starost, 10 (1), 2-15.

Dixon, S. (2003). Implications of population ageing for the labour market, in Labour Market trends, edited by A. Flowers, 67-76. London: Organisation for Economic Co-operation and Development.

Dolado, J.J., Felgueroso, F., \& Jimeno, J.F. (2000). Youth labour markets in Spain: Education, training, and crowding-out. European Economic Review, 44(4-6), 943-956, http://dx.doi.org/10.1016/S00142921(99)00050-1

Dubska, D. (2010). Nova paradigma - zakaj je pomembno, da se meri napredek družbe? [The new paradigm-why is important to measure the progress of society?]. Statistical days. Http://www.stat.si/StatisticniDnevi/Docs/ Radenci\%202010/Dubska_New\%20paradigm-prispevek.pdf (5.3.2011).

Dunsch, S. (2015). Okun's law and youth unemployment in Germany and Poland. European University Viadrina Frankfurt (ODER), Department of Business Administration and Economics, Discussion Paper No. 373. Retrieved October 8, 2015 from https://opus.zbw-kiel. de/dspace/bitstream/10419/120898/1/835448711.pdf

Eichhorst, W., Hinte, H., and Rinne, U. (2013). Youth Unemployment in Europe: What to Do about It? Institute for the Study of Labor (IZA) Policy Paper, No. 65. Retrieved October 5, 2015 from http://hdl.handle. net/10419/91749

Employment Service of Slovenia (ESS). (2011). Trg dela: Trg dela v številkah [Labour market: Labour market in figures]. Retrieved February 2, 2015 from http://www. ess.gov.si/trg dela/trg dela v stevilkah

European Centre for the Development of Vocational Training-CEDEFOP. (2012). Working and ageing. The benefits of investing in an ageing workforce. Luxembourg: Publications Office of the European Union.

Eurostat. (2015). Database, Population and social conditions, Labour market, Unemplyoment, Unemployment rate by sex and age groups - annual average, $\%$. Retrieved October, 23, 2015 from http://appsso. eurostat.ec.europa.eu/nui/submitViewTableAction.do
Eriksson, S., \& Dan-Olof, R. (2014). Do Employers Use Unemployment as a Sorting Criterion When Hiring? Evidence from a Field Experiment. American Economic Review, 104(3), 1014-39, http://dx.doi.org/10.1257/ aer.104.3.1014

European Commission. (2015). Growing the European Silver Economy. Background Paper. Brussels: European Commission. Retrieved October, 22, 2015 from http:// ec.europa.eu/research/innovation-union/pdf/active-healthy-ageing/silvereco.pdf\#view $=$ fit\&pagemode $=$ none

Fougere, M., Mercenier, J., \& Merette, M. (2007). A sectoral and occupational analysis of population ageing in Canada using a dynamic CGE overlapping generations model. Economic Modelling, 24(4), 690-711, http:// dx.doi.org/10.1016/j.econmod.2007.01.001

Gelagay, A. (2015). Factors affecting African American and Latin students' persistence in adult education programs. Doctoral dissertation, California State University, East Bay, United States of America.

Gervais, M., Jaimovich, N., Siu, H.E., \& Yedid-Levi, Y. (2014). What Should I Be When I Grow Up? Occupations and Unemployment over the Life Cycle. Working Paper No. 20628. The National Bureau of Economic Research (NBER). NBER Program: EFG, http://dx. doi.org/10.3386/w20628

Hinz, T., \& Jungbauer-Gans, M. (1999). Starting a business after unemployment: characteristics and chances of success (empirical evidence from a regional German labour market). Entrepreneurship \& Regional Development: An International Journal, 11(4), 317-333, http://dx.doi.org/10.1080/089856299283137

Hughes, N. (2011). Young People Took to the Streets and all of a Sudden all of the Political Parties Got Old: The 15M Movement in Spain. Social Movement Studies, 10 (4), 407-413, http://dx.doi.org/10.1080/14742837.201 $\underline{1.614109}$

Jackson, N. (2011). The demographic forces shaping New Zealand's future. What population ageing [really] means. Waikato: The University of Waikato: National Institute of Demographic and Economic Analysis.

Jousten, A., Lefèbvre, M., Perelman, S., \& Pestieau, P. (2010). The Effect of early retirement on youth unemployment. Chapter in The National Bureau of Economic Research (NBER) book Social Security Programs and Retirement around the World: The Relationship to Youth Employment ed. by Jonathan Gruber, J. \& Wise, D. A. (p. 47 - 76). Chicago: University of Chicago Press.

Katagiri, M. (2012). Economic Consequences of Population Aging in Japan: Effects through Changes in Demand Structure, IMES Discussion Paper Series from Institute for Monetary and Economic Studies, Bank of Japan, No 12-E-03.

Kurek, S., \& Rachwał, T. (2011). Development of entrepreneurship in ageing populations of The European Union. Procedia Social and Behavioral Sciences, 
19(2011), 397-405, http://dx.doi.org/10.1016/j.sbspro.2011.05.147

Lammers, M., Bloemen, H., \& Hochguertel, S. (2013). Job search requirements for older unemployed: Transitions to employment, early retirement and disability benefits. European Economic Review, 58, 31-57, http://dx. doi.org/10.1016/j.euroecorev.2012.11.003

Laporšček, S., \& Dolenc, P. (2011). Flexicurity in the European Union and Slovenia. Organizacija, 44(2), 7284.

Layard, R., Nickell, S., \& Jackman, R. (2005). Unemployment: Macroeconomic Performance and the Labour Market. Second Edition. New York: Oxford University Press.

Lešnik-Hren, J. (2003). Perspektive javnih zdravstvenih zavodov [Perspectives of public healthcare institutions], In: Management in razvoj organizacije, edited by J. Florjančič, 886-890. Kranj: Moderna organizacija.

Liang, J., Wang, H., \& Lazear, E.P. (2014). Demographics and Entrepreneurship. Working Paper No. 20506. The National Bureau of Economic Research (NBER). NBER Programs: Industrial Organization (IO); Labor Studies (LS), http://dx.doi.org/10.3386/w20506

Lisenkova, K., McGregor, P. G., Pappas, N., Swales, J. K., Turner, K., \& Wright R. E. (2010). Scotland the grey: a linked demographic-computable general equilibrium (CGE) analysis of the impact of population ageing and decline, Regional Studies, 44(10), 1351-1368, http:// dx.doi.org/10.1080/00343400701654228

Málaga, R., Oré, T., \& Tavera, J. (2014). Youth who neither work nor study: The Peruvian case. Economía, 37 (74), 95-132.

Malačič, J. (2008). Socialno ekonomske posledice staranja prebivalstva [Socioeconomic consequences of the population ageing], In: Zdravniški vestnik, edited by S. Markovič, 793-798. Ljubljana: Slovensko zdravniško društvo. Retrieved October 2, 2014 from http://www. szd.si/user_files/vsebina/Zdravniski_Vestnik/vestnik/ st08-12/793-798.pdf

Mandič, S., \& Filipovič-Hrast, M. (2011). Blaginja v starajoči se družbi: analitična izhodišča [Welfare in an ageing population: analytical basis], In: Blaginja pod pritiski demografskih sprememb, edited by Mandič, S., \& Filipovič-Hrast, M. Knjižna zbirka Ost, 9, 7-25. Ljubljana: Fakulteta za družbene vede. Retrieved September 30, 2015 from http://knjigarna.fdv.si/knjige/ sociologija/ost-osrednje-socioloske-teme/i 526 blaginja-pod-pritiski-demografskih-sprememb

Marič, M., Žnidaršič, J., Uhan, M., Dimovski, V., Ferjan, M., Djurica, M., Jeraj, M., \& Janežič, M. (2013). Country's Development as a Determinant of Early-Stage Entrepreneurial Activity. Organizacija, 46(3), 75-86, http://dx.doi.org/10.2478/orga-2013-0011

McDougall, R. (2010). Ageing populations and hidden unemployment. Optimum Population Trust (OPT),
Population Matters, London. Retrieved October 15, 2015 from http://populationmatters.org/resources/articles-reports-papers/ageing/

Michaelis, J., \& Debus, M. (2010). Wage and (un-)employment effects of an ageing workforce. Journal of Population Economics, 24(4), 1493-1511, http://dx. doi.org/10.1007/s00148-010-0325-9

Miles, D. (2005). Modelling the Impact of Demographic Change upon the Economy. The Economic Journal, 109 (452), 1-36, http://dx.doi.org/10.1111/1468$\underline{0297.00389}$

Obadić, A., \& Smolić, Š. (2008). The economic and social consequences of population ageing process. Ekonomska istraživanja, 21 (2), 86-98.

Osberg, L., \& Sharpe, A. (2011). Comparisons of Trends in GDP and Economic Well-being - the Impact of Social Capital, Retrieved October 15, 2015 from http://www. oecd.org/dataoecd/5/32/1824740.pdf

Penger, S., \& Dimovski, V. (2007). Strategija aktivnega staranja prebivalstva Slovenije s poudarkom na kakovostnem staranju in medgeneracijskem sožitju [Active population ageing strategy in Slovenia with a special emphasis on quality ageing and intergenerational solidarity]. IB revija (Ljubljana) 41 (1), 42-55.

Pešić, M. (2009). Effect of the introduction of the HAC$\mathrm{CP}$ international standard on an example in the food industry in Croatia. Ekonomska istraživanja, 22 (2), 132-147.

Rapa, D. (2014). An analysis of the possible determinants of youth unemployment in Malta. Doctoral dissertation, University of Malta, Faculty of Economics, Management and Accountancy, Department of Economics, Msida, Malta.

Rausch, S. (2009). Macroeconomic Consequences of Demographic Change. Modelling Issues and Applications. Berlin-Heidelberg: Springer. Http://dx.doi. org/10.1007/978-3-642-00146-8 (11.10.2015).

Samorodov, A. (1999). Ageing and labour markets for older workers. Geneva: International Labour Office.

Skirbekk, V. (2003). Age and individual productivity: a literature survey. MPIDR Working Paper WP 2003-028. Retrieved September 3, 2015 from https://www.google. si/url? $\mathrm{sa}=$ t\&rct $=\mathrm{j} \& \mathrm{q}=$ \&esrc $=$ s\& source $=$ web\&cd=1\&ved=0CCYQFjAAahUKEwj6hLazrurIAhXHRhQKHd-oCAU\&url=http $\% 3 \mathrm{~A} \% 2 \mathrm{~F} \% 2 \mathrm{Fwww}$. demogr.mpg.de $\% 2$ Fpapers $\% 2$ Fworking $\% 2 \mathrm{~F}$ wp-2003-028.pdf\&usg=AFQjCNG-1K T1TX0WBUOG_u_BCjSeJzX3w\&cad=rja

Stanovnik, T., \& Stropnik, N. (1999). Economic Well-being of the Elderly and Pension Reform in Slovenia. Economic Well-being of the Elderly and Pension Reform: Final Research Report, (2), 25-61. Retrieved October 26, 2015 from http://www.ier.si/files/Working\%20paper-02.pdf

Startiene, G., \& Remeikiene, R. (2009). The Influence of Demographical Factors on the Interaction between En- 
trepreneurship and Unemployment. Engineering Economics, 64(4), 60-70.

Statistical Office of the Republic of Slovenia (SORS). (2002). Demographic Indicators and the Methods of their Calculation. In Population of Slovenia 2000. Retrieved July 7, 2015 from http://www.stat.si/doc/pub/ rr776-2002/met izracun/izracun.htm

Statistical Office of the Republic of Slovenia (SORS). (2011a). SI-Stat Data Portal, Data by municipalities, Demography and social statistics, Population - selected indicators, municipalities, Slovenia, half-yearly. Retrieved February 2, 2015 from http://pxweb.stat. si/pxweb/Dialog/varval.asp?ma $=05$ C4008S\&ti $=$ \&path =../Database/Dem soc/05 prebivalstvo/10 stevilo preb/20 05C40 prebivalstvo obcine/\&lang $=2$

Statistical Office of the Republic of Slovenia (SORS). (2011b). SI-Stat Data Portal, Data by municipalities, Economy, Enterprises by municipalities, Slovenia, annually. Retrieved February 3, 2015 from http://pxweb.stat.si/pxweb/Dialog/varval.as$\mathrm{p} ? \mathrm{ma}=1418807 \mathrm{E} \& \mathrm{ti}=$ Enterprises $+\mathrm{by}+$ municipalities $\% 2 \mathrm{C}+$ Slovenia $\% 2 \mathrm{C}+$ annually \&path $=$. ./Database/ Economy/14 business subjects/01 14188 Enterprises/\&lang $=1$

Statistical Office of the Republic of Slovenia (SORS). (2011c). SI-Stat Data Portal, Data by municipalities, Demography and social statistics, Labour force, Persons in employment, registered unemployed persons and registered unemployment rates by municipalities of residence, Slovenia, monthly. Retrieved February 3, 2015 from http://pxweb.stat.si/pxweb/Dialog/varval.asp?ma $=0700960 \mathrm{E} \& \mathrm{ti}=\&$ path $=$. ./Database $/ \mathrm{De}-$ mographics $/ 07$ labour force $/ 05$ labour force register/01 07009 aktivno preb mesecno/\&lang $=1$

Statistical Office of the Republic of Slovenia (SORS). (2014). Methods and classifications, Methodological explanations, Labour market, Employees, Self-Employed and Unemployed, Labour force, Slovenia. Retrieved August 8, 2015 from http://www.stat.si/ statweb/Common/PrikaziDokument.ashx?IdDatote$\mathrm{ke}=8321$

Statistical Office of the Republic of Slovenia (SORS). (2015). SI-Stat Data Portal, Demography and social statistics, Number of Population, Number of Population, statistical regions, Population - selected indicators, statistical regions, Slovenia, half-yearly. Retrieved April 4, 2015 from http://pxweb.stat.si/pxweb/Dialog/varval.asp?ma $=05$ C2008S\&ti $=\&$ path $=. . /$ Database/Dem soc/05 prebivalstvo/10 stevilo_preb/10 05C20 prebivalstvo stat regije/\&lang $=1$

Thurik, A. R. (2003). Entrepreneurship and Unemployment in the UK. Scottish Journal of Political econo$m y$, 50(3), 264-290, http://dx.doi.org/10.1111/1467$\underline{9485.5003001}$

Thurik, A. R., \& Verheul, I. (2003). The relationship between entrepreneurship and unemployment: the case of Spain, in Geneseca, E., Urbano, D., Capelleras, J.L., Guallarte, C., Verges, J. (eds.), Creacion de Empresas, Entrepreneurship. Barcelona, Spain: Servei de Publicacions de la UAB.

Thurik, A. R., Caree, M. A., van Stel, A., \& Audretsch, D. B. (2008). Does self-employment reduce unemployment? Journal of Business Venturing, 23(6), 673-686, http://dx.doi.org/10.1016/j.jbusvent.2008.01.007

United Nations. (2006). World population prospects 2006. New York: United Nations.

United States Census Bureau. (2011). International Data Base. Retrieved February 3, 2011 from http://www. census.gov/ipc/www/idb/country.php

Wach, K. (2015). Entrepreneurial Orientation and Business Internationalisation Process: The Theoretical Foundations of International Entrepreneurship. Entrepreneurial Business and Economics Review, 3(2), 9-24, http:// dx.doi.org/10.15678/EBER.2015.030202

Watson, D., F. Pichler, \& Waallace, C. (2010). Subjective Well-being in Europe: Second European Quality of Life Survey, Luxembourg: Office for Official Publications of European Communities.

Weber, S. \& Lehtinen, E. (2014). Transition from Schoolto-Work and its challenges. Unterrichtwissenschaft, 42 (3), 194-205.

Zhang, M. M., Peppas, S., Peppas, S., \& Yu, T. T. (2015) The great recession: a statistical analysis of its effects on unemployment. International Journal of Business \& Economics Perspectives, 10(1), 44-54.

Marjetka Troha Akanni received her Bachelor's degree from marketing in 2008 on Faculty of Management, University of Primorska. She also completed her Master's degree entitled Population ageing and economics welfare in Slovenia in 2012 on Faculty of Management, University of Primorska. Currently she is employed in Lekšan d.o.o.

Žiga Čepar received his Bachelor's degree in Economics, Finance in 2000 on Faculty of Economics, University of Ljubljana. In 2009 he defended his doctoral dissertation on Faculty of management, University of Primorska. Before entering an academic sphere he worked in Nova Ljubljanska banka d.d. in department for financial institutions and international. Currently he is employed at Faculty of Management, University of Primorska as an associate professor, where he teaches Economics of Enterprise, Microeconomics, Macroeconomics, Political Economics and International Economics on the undergraduate as well as on the postgraduate level. His research areas are demography, economics, education and labour market. 